\title{
LEADERSHIP IN VIRTUAL TEAMS
}

\section{Ana Radulović ${ }^{1 *}$, Olga Epitropaki²}

${ }^{1}$ Singidunum University, Belgrade, Serbia

Durham University, Durham, UK

\begin{abstract}
:
Rapid technological advancements and process automation have enabled organizations to manage their work across time and space, that is, to create virtual teams. In the paper we differentiate between leadership in traditional and virtual work contexts. Additionally, we outline the challenges that leaders of virtual teams face. Furthermore, we identify transformational and transactional leadership styles as the two most impactful hierarchical leadership styles and outline their outcomes in virtual teams. Moreover, we outline the outcomes of shared leadership in virtual teams. Lastly, we summarize the impacts of research on leadership in virtual teams.
\end{abstract}

Keywords:

leadership, virtual teams, transformational, transactional, shared.

\section{INTRODUCTION}

Fast technological developments and process automation have enabled organizations to conduct their work across time and space. As a consequence, numerous communication technologies used in the virtual working environment have provided a new context for leadership and teamwork. Leadership is defined as a process by which individuals use their intentional influence to guide, structure, and facilitate activities and relationships in groups or organizations (Yukl, 2010). Indeed, leaders are expected to encourage, motivate, and manage subordinates' performance mostly through their physical presence. Due to the changes in the work context, virtual leadership has been conceptualized as a process of social influence that is enabled by advanced information technologies to generate changes in organizations, groups and individuals regarding their performance, behaviors, thinking and attitudes (Avolio, Kahai, \& Dodge, 2000). Recently, the COVID-19 pandemic has intensified the need for leaders to ensure effectiveness of their remote teams (Bartsch, Weber, Büttgen, \& Huber, 2020; Feitosa \& Salas, 2020). Therefore, leadership in virtual teams is relevant more than ever before.

Teams represent groups of individuals who work on interdependent tasks; they are mutually responsible for team performance and are perceived as a social entity (Cohen \& Bailey, 1997). Teamwork has also been affected by the virtual context and new technologies that facilitate their functioning. Therefore, virtual teams are defined as symbiotic groups of individuals whose communication heavily depends on advanced information technologies which enable them to operate beyond time, space and organizational limitations (Hambley, O’Neill, \& Kline, 2007). These types of work units are becoming increasingly common in many organizations. 
They enable organizations to enhance their productivity by minimizing operational costs and by allocating tasks to the most appropriate human resource (Huang, Kahai, \& Jestice, 2010).

Extensive reliance on technology can impede communication in virtual teams and cause confusion regarding the progress of their work. Indeed, the absence of face-toface interaction can limit a leader's ability to provide guidance, feedback and perform other functions (Hambley et al., 2007). Members of virtual teams often experience a low level of team cohesion and trust, especially if they did not interact previously. Furthermore, virtual team members tend to have different backgrounds and thus different norms and procedures for completing work. Moreover, physical separation of team members can lessen the significance of the team and its objectives (Hambley et al., 2007). Considering the challenges of virtual environment, an important question is what leadership style is the most appropriate for virtual teams. This topic has been the focus of numerous empirical studies. Scholars have referred to virtual leadership as formal or hierarchical leadership by which one person assumes the role of a leader within the group and as shared leadership by which the leadership role is shared among its members. In this paper we identified three most prominent leadership styles in the literature on virtual teams, namely transformational, transactional and shared leadership. Additionally, we review the impact of these leadership styles on the outcomes of virtual teams. Lastly, we outline the implications of leadership in virtual teams.

\section{TRANSFORMATIONAL AND TRANSACTIONAL LEADERSHIP}

Transformational leadership is a process by which leaders inspire followers to accept and pursue leader's vision and motivate them to transcend their own self-interest for the sake of the group interests (Bass, 1985). As a multidimensional construct, transformational leadership involves four dimensions; idealized influence, inspirational motivation, intellectual stimulation and individualized consideration (Bass \& Avolio, 1993). Each of these dimensions significantly impacts followers' experience of the leadership process.

Idealized influence or charisma is the emotional component of leadership. Charismatic leaders represent role models for their followers who easily identify with them. These leaders demonstrate high standards of moral and ethical conduct which their subordinates aim to emulate. Charismatic leaders articulate attractive vision and mission for their subordinates. Inspirational motivation entails communicating high expectations to followers. Leaders inspire their subordinates through motivation to pursue organizational vision. Furthermore, leaders enable group members to achieve more than they would do on their own with the use of symbols and emotional appeals. In doing so, inspirational leaders strengthen team spirit.

Intellectual stimulation involves leadership that encourages followers to be creative and innovative. Leaders challenge assumptions, including their own, subordinates' and organization's values and beliefs. Followers are encouraged to try new approaches to addressing organizational issues. Furthermore, free expression of thought and creative problem solving is encouraged. Lastly, individualized consideration enables leaders to create a supportive climate in which they cater for followers' individual needs, abilities and aspirations. Leaders aim to fully develop followers' potential by providing guidance, coaching and mentoring (Bass, 1985; Yukl, 2010).

In contrast, transactional leadership involves a process of exchange with followers that generates mutual benefits (Bass \& Avolio, 1993). The power of transactional leaders lies in the fact that followers will be rewarded if they do what the leader wants. In a similar vein, followers comply with leaders' expectations to avoid punishments. Transactional leadership is based on two factors: contingent reward and management by exception.

Contingent reward implies that followers' efforts are exchanged for specific rewards. This approach to leadership enables leaders to gain follower's agreement on what needs to be achieved and benefits for people who achieve it. Management-by-exception involves leadership that utilizes negative criticism, negative feedback and negative reinforcement when subordinates underperform. A transactional leader will therefore offer prizes, praise, compliments, and rewards when objectives are achieved. Team processes are facilitated by providing clarifications of roles and task expectations which are then reinforced through contingent rewards. In contrast, when subordinates fail to achieve outlined objectives, a transactional leader uses negative reinforcements such as punishments (Bass, 1998).

Transformational and transactional approaches to leadership have attracted attention of numerous studies over the last decade. Interestingly, transformational leadership was found to be more effective than transactional leadership (Bass, 1997; Judge \& Piccolo, 2004). While transactional leadership focuses on expected results, transformational leadership focuses on performance that exceeds what is expected. The results of meta-analysis showed that transformational leadership, rather than transactional leadership, had a greater impact on followers' job satisfaction, satisfaction with leader, motivation, leader performance, effectiveness, and group/organization performance (Judge \& Piccolo, 2004). Transformational leadership is also relevant in virtual teams whose members 
face the challenge of being in different geographical locations and time zones. The following section outlines the impact of transformational and transactional leadership styles on various aspects of virtual and traditional teams.

\section{THE OUTCOMES OF TRANSFORMATIONAL AND TRANSACTIONAL LEADERSHIP IN VIRTUAL TEAMS}

Several studies investigated the impact of transformational and transactional leadership on virtual teams. One study, in particular, examined the level of team-members' satisfaction and perception of the leadership style. Findings suggested that virtual team members were more satisfied with a transformational leadership style than with a transactional style. Additionally, team members preferred transformational leadership over transactional leadership (Ruggieri, 2009).

Another study involved employees working in virtual teams in a Fortune 500 hardware and software multinational corporation. It was found that inspirational leadership significantly influenced team members' trust and commitment to the team. Furthermore, the positive association between inspirational leadership and employees' trust and commitment was stronger in teams that were more dispersed. While inspirational leadership is vital for all working environments, its relevance is particularly highlighted in virtual teams or highly dispersed work contexts (Joshi, Lazarova, \& Liao, 2009).

Researchers examined the link between personality aspects and transformational leadership emergence by comparing virtual teams with face-to-face teams. The results demonstrated that extraversion and emotional stability contributed to transformational leadership emergence in face-to-face teams. Interestingly, the linguistic quality of virtual team members' written communication triggered transformational leadership emergence in virtual teams (Balthazard, Waldman, \& Warren, 2009).

In a similar vein, another study examined transformational leadership by comparing traditional teams that used face-to-face communication with virtual teams that relied on computer-mediated communication. The study involved thirty-nine leaders who supervised both types of teams. The results showed that the most effective leaders were the ones who enhanced their transformational leadership in virtual teams. Interestingly, team-level analysis showed that transformational leadership had a greater effect on team performance in virtual teams rather than on performance in traditional teams. Furthermore, team members' evaluation of transformational leadership was equally associated with project satisfaction in both traditional and virtual teams.
Overall, the findings suggested that transformational leadership had a greater impact on teams that relied on computer-mediated communication only. Leaders who enhanced their transformational leadership behaviors in virtual teams attained greater team performance (Purvanova \& Bono, 2009).

Cooperative climate involves the common impression of the members that the team provides them with support and safety as they strive to achieve their objectives (Chen \& Huang, 2007). Team cohesion is a dynamic feature of a team that reflects a group's tendency to remain in a group (Festinger, 1950). Members are motivated to remain a part of the group because of interpersonal attraction (i.e., social cohesion) and shared commitment to the group task (i.e., task cohesion, Hackman, 1987). A medium's richness is rooted in its ability to deliver several cues, immediate feedback, language variety and personalization (Daft \& Lengel, 1986). The richest media is face-to-face communication, which is followed by telephone, chat, e-mail, and print communication (Webster \& Hackley, 1997). The findings of another study suggest that transactional leadership enhanced team task cohesion, while transformational leadership enhanced cooperative climate. Cooperative climate, subsequently, enhanced task cohesion. Nevertheless, the impact of leadership style is contingent on media richness, as it unfolds only when media richness is low (Huang et al., 2010).

More recently, a study investigated the challenges that virtual team leaders face. In particular, the study examined how transformational leaders may develop high-quality relationships with their remote subordinates considering team task interdependence and electronic dependence (Wong \& Berntzen, 2019). The results showed that transformational leadership was negatively associated with relationship quality when teams were high in both task interdependence and electronic dependence. Therefore, the study indicates that transformational leadership may not always be effective in virtual teams (Wong \& Berntzen, 2019). Therefore, future studies should explore other leadership styles appropriate for virtual teams.

\section{SHARED LEADERSHIP}

Another approach to leadership that has been shown to be effective in virtual teams is shared leadership. Shared leadership is a process by which all team members are completely involved in leading the team. That is, shared leadership encourages a simultaneous, ongoing and mutual influence of team members by which every member has an opportunity to emerge as an official or unofficial leader of the team (Pearce \& Manz, 2005). Empirical studies of shared leadership include top management teams, change management teams, sales teams, and extreme action teams (Muethel \& Hoegl, 2010). 
Shared team leadership is argued to encourage the creation of stronger bonds between the team members, commitment, cohesion and trust, and lessen the shortcomings of virtual teams. Indeed, when team members share leadership function, they balance hierarchical leadership in virtual teams (Hoch \& Kozlowski, 2014). Communication in virtual teams is less formal and less hierarchical and, thus, team members are more likely to overcome communication obstacles. Likewise, virtual team members work on the cognitively demanding tasks that are vastly interdependent, yet autonomous. Therefore, shared leadership is viewed as more suitable approach to leading teams than hierarchical leadership in which one person dominates (Hoch \& Kozlowski, 2014).

\section{THE OUTCOMES OF SHARED LEADERSHIP IN VIRTUAL TEAMS}

Scholars have recently begun to investigate shared leadership in virtual teams. A study that examined 96 virtual teams showed that shared leadership encourages team performance (Muethel, Gehrlein, \& Hoegl, 2012). Additionally, it was found that the structure of virtual teams enhanced shared leadership.

A study of 44 virtual teams investigated the extent to which shared leadership, autonomy and team members' trust influenced satisfaction of team members (Robert Jr \& You, 2018). It was revealed that shared leadership enabled satisfaction in virtual teams both directly and indirectly through the promotion of trust. Namely, shared leadership moderated the effects of individual autonomy and individual trust on satisfaction. Satisfaction within the team significantly influenced performance of the team (Robert Jr \& You, 2018).

Another study involving 101 virtual teams investigated the effect of traditional hierarchical leadership and shared team leadership on team performance. It was expected that shared leadership, rather than hierarchical leadership, would have a greater impact on team performance when teams were more virtual. Indeed, the results showed that the degree of team virtuality lessened the association between hierarchical leadership and team performance. Nevertheless, shared team leadership was associated with team performance irrespective of their virtuality (Hoch \& Kozlowski, 2014).

\section{CONCLUSION}

The pervasiveness of technological advancements has enabled employees to work in teams from any place at any time. Nevertheless, this geographical dispersion may have a negative impact on the members of virtual teams, especially on their trust, commitment, and satisfaction. Furthermore, leaders may find it more difficult to ensure the optimal levels of cohesion, climate and performance in virtual teams. It was found that virtual team members preferred transformational over transactional leadership style (Ruggieri, 2009). Likewise, inspirational leadership is particularly relevant for dispersed work contexts (Joshi et al., 2009), although high electronic dependence and task interdependence could inhibit the development of highquality relationships between a leader and subordinates (Wong \& Berntzen, 2019). Moreover, scholars compared the impact of transformational leadership on both traditional and virtual teams. The results showed that transformational leadership had a greater impact on performance of virtual teams than on performance of traditional teams (Purvanova \& Bono, 2009). While transformational leadership is considered to be a formal or hierarchical leadership style appropriate for both traditional and virtual teams, research has recently shown that shared leadership is particularly relevant for virtual teams. Namely, shared leadership contributed to the satisfaction (Robert Jr \& You, 2018) and performance (Muethel et al., 2012) of virtual teams. It was also found that shared team leadership contributed to the team performance regardless of the extent to which teams were virtual (Hoch \& Kozlowski, 2014). Future research should continue to investigate the ways in which hierarchical and shared leadership styles could have positive impact on virtual teams.

\section{LITERATURE}

Avolio, B. J., Kahai, S., \& Dodge, G. E. (2000). E-leadership: Implications for theory, research, and practice. The Leadership Quarterly, 11(4), 615-668.

Balthazard, P. A., Waldman, D. A., \& Warren, J. E. (2009). Predictors of the emergence of transformational leadership in virtual decision teams. The Leadership Quarterly, 20, 651-663.

Bartsch, S., Weber, E., Büttgen, M., \& Huber, A. (2020). Leadership matters in crisis-induced digital transformation: how to lead service employees effectively during the COVID-19 pandemic. Journal of Service Management.

Bass, B. M. (1985). Leadership and performance beyond expectations. New York: Free Press.

Bass, B. M. (1997). Does the transactional-transformational leadership paradigm transcend organizational and national boundaries? American Psychologist, 52(2), 130-139. 
Bass, B. M. (1998). The ethics of transformational leadership. In J. B. Ciulla (Ed.), Ethics, the heart ofleadership (pp. 169-192). Wesrport, CT: Praeger

Bass, B. M., \& Avolio, B. J. (1993). Transformational leadership: A response to critiques. In M. M. Chemers \& R. Ayman (Eds.), Leadership theory and research: Perspectives and directions (pp. 49-80). San Diego, CA: Academic Press.

Chen, C.-J., \& Huang, J.-W. (2007). How organizational climate and structure affect knowledge managementThe social interaction perspective. International journal of information management, 27(2), 104-118.

Cohen, S. G., \& Bailey, D. E. (1997). What makes teams work: Group effectiveness research from the shop floor to the executive suite. Journal of Management, 23(3), 239-290.

Daft, R. L., \& Lengel, R. H. (1986). Organizational information requirements, media richness and structural design. Management Science, 32(5), 554-571.

Feitosa, J., \& Salas, E. (2020). Today's virtual teams: Adapting lessons learned to the pandemic context. Organizational dynamics.

Festinger, L. (1950). Informal social communication. Psychological review, 57(5), 271-282.

Hackman, J. R. (1987). The design of work teams. In J. W. Lorsch (Ed.), Handbook of organizational behavior (pp. 315-342). Englewood Cliffs, NJ: Prentice-Hall.

Hambley, L. A., O’Neill, T. A., \& Kline, T. J. (2007). Virtual team leadership: The effects of leadership style and communication medium on team interaction styles and outcomes. Organizational behavior and human decision processes, 103, 1-20.

Hoch, J. E., \& Kozlowski, S. W. (2014). Leading virtual teams: Hierarchical leadership, structural supports, and shared team leadership. Journal of Applied Psychology, 99, 390-403.

Huang, R., Kahai, S., \& Jestice, R. (2010). The contingent effects of leadership on team collaboration in virtual teams. Computers in Human Behavior, 26(5), 1098-1110.

Joshi, A., Lazarova, M. B., \& Liao, H. (2009). Getting everyone on board: The role of inspirational leadership in geographically dispersed teams. Organization Science, 20(1), 240-252.
Judge, T. A., \& Piccolo, R. F. (2004). Transformational and transactional leadership: a meta-analytic test of their relative validity. Journal of Applied Psychology, 89(5), 755-768.

Muethel, M., Gehrlein, S., \& Hoegl, M. (2012). Socio-demographic factors and shared leadership behaviors in dispersed teams: Implications for human resource management. Human Resource Management, 51(4), 525-548.

Muethel, M., \& Hoegl, M. (2010). Cultural and societal influences on shared leadership in globally dispersed teams. Journal of International Management, 16, 234-246.

Pearce, C. L., \& Manz, C. C. (2005). The new silver bullets of leadership: The importance of self-and shared leadership in knowledge work. Organizational dynamics, 34, 130-140.

Purvanova, R. K., \& Bono, J. E. (2009). Transformational leadership in context: Face-to-face and virtual teams. The Leadership Quarterly, 20(3), 343-357.

Robert Jr, L. P., \& You, S. (2018). Are you satisfied yet? Shared leadership, individual trust, autonomy, and satisfaction in virtual teams. Journal of the association for information science and technology, 69(4), 503-513.

Ruggieri, S. (2009). Leadership in virtual teams: A comparison of transformational and transactional leaders. Social Behavior \& Personality: An International Journal, 37(8), 1017-1022.

Webster, J., \& Hackley, P. (1997). Teaching effectiveness in technology-mediated distance learning. Academy of Management Journal, 40(6), 1282-1309.

Wong, S. I., \& Berntzen, M. N. (2019). Transformational leadership and leader-member exchange in distributed teams: The roles of electronic dependence and team task interdependence. Computers in Human Behavior, 92, 381-392.

Yukl, G. (2010). Leasership in organizations ( $7^{\text {th }}$ ed.). Upper Saddle River, NJ: Pearson. 